\title{
Preliminary Studies about Synthesis and Electrical Properties of Ruthenium Doped Lanthanum Strontium Titanate as a Potential Anode of Solid Oxide Fuel Cells
}

\author{
Heechul Yoon, Jing Zou, Sungtae Park, Nigel Mark Sammes, and Jong Shik Chung \\ Department of Chemical Engineering, Pohang University of Science and Technology \\ (POSTECH), San 31, Hyoja-Dong, Nam-Gu, Pohang 790-784, Republic of Korea
}

\begin{abstract}
The lanthanum strontium titanate (LST) is one of the most representative alternative anode materials. Although it shows low catalytic properties, the disadvantage could be improved by doping of ruthenium which is widely used as catalyst under steam reforming reaction or oxidation reaction. The ruthenium doped lanthanum strontium titanates (LSTRs) powders were synthesized by complex EDTA-citrate method showing well crystallinity. Additionally, the prepared samples were evaluated through various experimental tests. For example, the stability in the reducing atmosphere and chemical compatibility with YSZ electrolyte such as reactivity test in high temperature were confirmed by XRD (Xray diffraction). And electrical conductivity in wet $\mathrm{H}_{2}$ atmosphere at $900{ }^{\circ} \mathrm{C}$ is about $350.6 \mathrm{~S} / \mathrm{cm}, 342.4 \mathrm{~S} / \mathrm{cm}$ and $179.1 \mathrm{~S} / \mathrm{cm}$ with sintered bar of LST, LSTR0.02 and LSTR0.05, respectively.
\end{abstract}

\section{Introduction}

Solid oxide fuel cells (SOFCs) are one of the most promising energy conversion devices converting chemical energy into electrical energy. The Ni/YSZ cermet is widely used as anode material showing good catalytic activity and high electrical conductivity. However, there are some problems including not only volumetric change during oxidationreduction cycling atmosphere but also carbon deposition when using hydrocarbon as fuel (1-3). Especially, it can causes degradation of performance as well as serious crack in the cell or stack.

From a few decades ago, it has been proposed that these problems mentioned above could be overcome by using alternative anode materials that satisfy the requirements. Some researchers suggest that alternative anode material such as lanthanum doped strontium titanate (LST) showing remarkable electrical conductivity in anodic atmosphere and resistance to sulfur $(4,5)$ can overcome these problems. However, lanthanum doped strontium titanates also have fatal disadvantages such as low activity under fuel oxidation reaction and steam reforming reaction unfortunately. So, it requires the substitution or addition of catalyst materials in order to improve the catalytic activity (6-8).

In this study, we added small amount of ruthenium to lanthanum strontium titanate structure and compared it with pure lanthanum strontium titanate. The ruthenium doped lanthanum strontium titanate powders having various ratio $\left(\mathrm{La}_{0.4} \mathrm{Sr}_{0.6} \mathrm{Ti}_{1-\mathrm{x}} \mathrm{Ru}_{\mathrm{x}} \mathrm{O}_{3}, \mathrm{x}=0\right.$, $0.02,0.05)$ were well synthesized by complex EDTA-citrate method. To carry out 
preliminary studies of ruthenium doped lanthanum strontium titanate as to be anode materials, reducing stability test and reactivity with YSZ electrolyte test were conducted. Also, the electrical conductivity as function of temperature and doping amount of ruthenium was measured.

\section{Experimental}

\section{$\underline{\text { Synthesis }}$}

LSTR ( $\left.\mathrm{La}_{0.4} \mathrm{Sr}_{0.6} \mathrm{Ti}_{1-\mathrm{x}} \mathrm{Ru}_{\mathrm{x}} \mathrm{O}_{3}, \mathrm{x}=0,0.02,0.05\right)$ powders were synthesized by complex EDTA-citrate method from starting materials of $\mathrm{La}\left(\mathrm{NO}_{3}\right)_{3} \cdot \mathrm{xH}_{2} \mathrm{O}$ (Sigma-Aldrich, 99.9\%), $\mathrm{Sr}\left(\mathrm{NO}_{3}\right)_{2}$ (Samchun Chemicals, 98\%), $\mathrm{C}_{12} \mathrm{H}_{28} \mathrm{O}_{4} \mathrm{Ti}$ (Sigma-Aldrich, 97\%) and $\mathrm{RuO}_{2}$ (Sigma-Aldrich, 99.9\%). Approximate synthesis process is a little similar with modified EDTA-citrate method (9), but a few more processes were added.

For the complex EDTA-citrate method, three of the beakers filled with distilled water, absolute alcohol and nitric acid respectively were prepared. Firstly, $\mathrm{La}\left(\mathrm{NO}_{3}\right)_{3} \cdot \mathrm{xH}_{2} \mathrm{O}$ and $\mathrm{Sr}\left(\mathrm{NO}_{3}\right)_{2}$ with stoichiometric quantity were dissolved in EDTA $\left(\mathrm{C}_{10} \mathrm{H}_{16} \mathrm{~N}_{2} \mathrm{O}_{8}\right.$, SigmaAldrich)-distilled water solution after the EDTA was completely dissolved in distilled water by addition of ammonia solution $\left(\mathrm{NH}_{3}\right.$, Samchun Chemicals). Under agitation states, citric acid $\left(\mathrm{C}_{6} \mathrm{H}_{8} \mathrm{O}_{7}\right.$, Sigma-Aldrich) was added to the solution. And then, ammonia solution was added more to maintain the $\mathrm{pH}$ value of $6 \sim 7$. The molar ratio of total metal cations to EDTA was 1:1 and of total amount of $\mathrm{La}, \mathrm{Sr}$ and $\mathrm{Ru}$ metals cation to citric acid was 1:1.5. Secondly, $\mathrm{C}_{12} \mathrm{H}_{28} \mathrm{O}_{4} \mathrm{Ti}$ with stoichiometric quantity were dissolved in absolute ethanol containing citric acid. The molar ratio of Ti metal cation to citric acid was 1:1.5. On the other hand, the $\mathrm{C}_{12} \mathrm{H}_{28} \mathrm{O}_{4} \mathrm{Ti}$ could be precipitated if it was in contact with distilled water. So, it could interfere with homogeneous synthesis. Therefore, absolute ethanol was used. Finally, $\mathrm{RuO}_{2}$ with stoichiometric quantity was dissolved in nitric acid to form the nitrate solution. Then, all of the three solutions were mixed together in one beaker with final molar ratio of 1:1:1.5 for total metal cations : EDTA : citric acid. The $\mathrm{pH}$ value of the solution was kept at $6 \sim 7$ by adding the ammonia solution and the temperature of solution were maintained at $80{ }^{\circ} \mathrm{C}$ until it changes to dark brown gel. When the samples were change to gel, temperature was raised to $200{ }^{\circ} \mathrm{C}$ for $1 \mathrm{~h}$ in low-temperature furnace. After heat treatment, huge scale increase of volume was observed. Then, pre-calcination was performed at $700{ }^{\circ} \mathrm{C}$ for $1 \mathrm{~h}$, followed by ball-milling with ethanol for a day to increase homogeneity of the powder. And then, dried powder was calcined at $1050{ }^{\circ} \mathrm{C}$ for $5 \mathrm{~h}$, followed by ball-milling with ethanol again for a day. The phase structure of prepared powders was characterized through X-ray diffraction (D/Max-2500/PC, Rigaku, Japan) using $\mathrm{Cu} \mathrm{K \alpha}$ radiation with 40 kV, 200 mA conditions.

\section{$\underline{\text { Reducing Stability and Reactivity with YSZ Electrolyte }}$}

The reducing stability of LST and LSTRs was confirmed by comparing XRD patterns before and after exposing at $900{ }^{\circ} \mathrm{C}$ in wet $\mathrm{H}_{2}$ for $10 \mathrm{~h}$. And, to study chemical compatibility, YSZ widely used as electrolyte was mixed with LST and LSTRs powders (YSZ : LST or LSTR $=50 \mathrm{wt} \%: 50 \mathrm{wt} \%$ ), followed by ball-milling for a day. After drying it, the mixed powders were annealed at $1300{ }^{\circ} \mathrm{C}$ for $10 \mathrm{~h}$ in air. 


\section{Conductivity Measurement}

The prepared powders were pressed into bars using rectangular type mold and then fired at $1400{ }^{\circ} \mathrm{C}$ in $10 \% \mathrm{H}_{2}$ balanced by $\mathrm{Ar}$ for $5 \mathrm{~h}$ for electrical conductivity measurements. The electrical conductivity of LST and LSTRs as function of temperature and doping amount of ruthenium in wet $\mathrm{H}_{2}$ atmosphere was obtained using standard DC four-prove technique with modular galvano technique of a VSP-300 device (Bio-Logic Science Instruments, France). The measurements were performed upon cooling from $900{ }^{\circ} \mathrm{C}$ to $500{ }^{\circ} \mathrm{C}$ at $50{ }^{\circ} \mathrm{C}$ per step. Finally, the measured values were corrected by the relative density obtained by Archimedes principle.

\section{Results and Discussion}

Figure 1 shows the XRD patterns of the prepared $\mathrm{La}_{0.4} \mathrm{Sr}_{0.6} \mathrm{TiO}_{3}$, $\mathrm{La}_{0.4} \mathrm{Sr}_{0.6} \mathrm{Ti}_{0.98} \mathrm{Ru}_{0.02} \mathrm{O}_{3}$ and $\mathrm{La}_{0.4} \mathrm{Sr}_{0.6} \mathrm{Ti}_{0.95} \mathrm{Ru}_{0.05} \mathrm{O}_{3}$ synthesized by complex EDTA-citrate method. All of the patterns were well matched with cubic structure of strontium titanate with JCPDS card of number 86-0178 indicating Ru was well inserted into the structure of lanthanum strontium titanate structure. And, the main peaks shifted to the left as doping amount of the Ru increased by lattice expansion. Because the ionic radii of $\mathrm{Ru}^{4+}$ is $0.62 \AA$ which is relatively larger than that of $\mathrm{Ti}^{4+}(0.605 \AA)$ so lattice parameter and volume of cubic cell increase as doping amount of $\mathrm{Ru}$ increases. The lattice parameter and cell volume were calculated by cell refinement of jade software 5.0 as shown in Table 1.

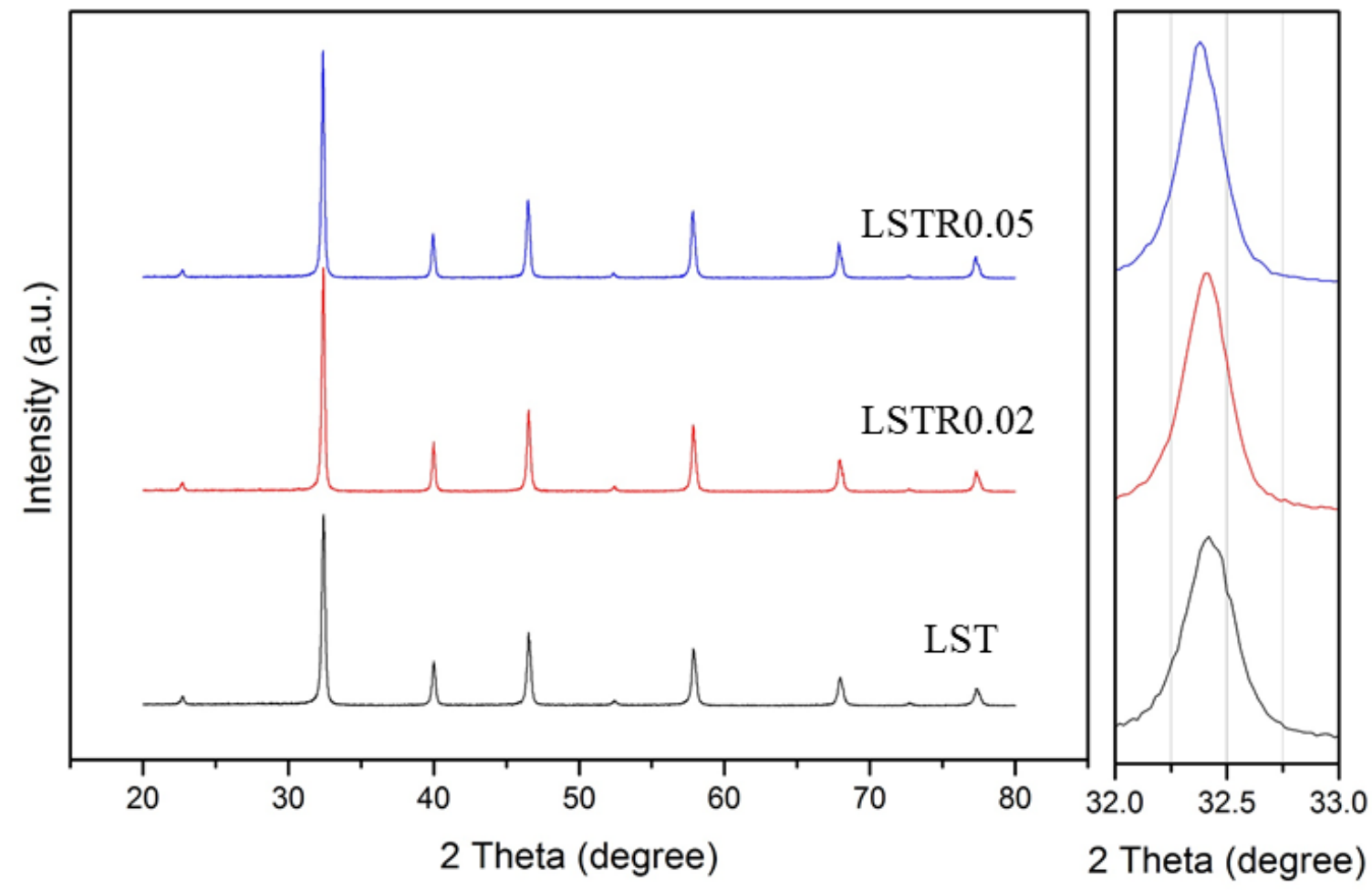

Figure 1. XRD patterns of $\mathrm{La}_{0.4} \mathrm{Sr}_{0.6} \mathrm{TiO}_{3}, \quad \mathrm{La}_{0.4} \mathrm{Sr}_{0.6} \mathrm{Ti}_{0.98} \mathrm{Ru}_{0.02} \mathrm{O}_{3}$ and $\mathrm{La}_{0.4} \mathrm{Sr}_{0.6} \mathrm{Ti}_{0.95} \mathrm{Ru}_{0.05} \mathrm{O}_{3}$ powders calcined at $1050{ }^{\circ} \mathrm{C}$ for $5 \mathrm{~h}$ and magnification of the main peak region. 
TABLE I. Lattice Parameters of $\mathrm{La}_{0.4} \mathrm{Sr}_{0.6} \mathrm{TiO}_{3}, \mathrm{La}_{0.4} \mathrm{Sr}_{0.6} \mathrm{Ti}_{0.98} \mathrm{Ru}_{0.02} \mathrm{O}_{3}$ and $\mathrm{La}_{0.4} \mathrm{Sr}_{0.6} \mathrm{Ti}_{0.95} \mathrm{Ru}_{0.05} \mathrm{O}_{3}$ Powders

\begin{tabular}{ccccc}
\hline Sample & Abbreviation & $\begin{array}{c}\text { Main peak } \\
\text { position }\end{array}$ & $\begin{array}{c}\text { Lattice } \\
\text { paremeter }(\boldsymbol{\AA})\end{array}$ & $\begin{array}{c}\text { cell } \\
\text { Volume }\left(\AA^{3}\right)\end{array}$ \\
\hline $\mathrm{La}_{0.4} \mathrm{Sr}_{0.6} \mathrm{TiO}_{3}$, & LST & 32.42 & 3.8991 & 59.28 \\
$\mathrm{La}_{0.4} \mathrm{Sr}_{0.6} \mathrm{Ti}_{0.98} \mathrm{Ru}_{0.02} \mathrm{O}_{3}$ & LSTR0.02 & 32.41 & 3.8995 & 59.3 \\
$\mathrm{La}_{0.4} \mathrm{Sr}_{0.6} \mathrm{Ti}_{0.95} \mathrm{Ru}_{0.05} \mathrm{O}_{3}$ & LSTR0.05 & 32.38 & 3.90194 & 59.41 \\
\hline
\end{tabular}

In order to use as anode material, physical and chemical stability in reducing condition which is one of the most important properties should be required because it is exposed to a fuel atmosphere during operation. Figure 2 presents the XRD patterns of the LST, LSTR0.02, LSTR0.05 after exposing at $900{ }^{\circ} \mathrm{C}$ in wet $\mathrm{H}_{2}$ for $10 \mathrm{~h}$. As determined from XRD patterns, impurity peaks and disappeared peaks were not found after exposure to reducing atmosphere. This result indicates that the samples show good reducing stability under the condition of $900{ }^{\circ} \mathrm{C}$ in wet $\mathrm{H}_{2}$ for $10 \mathrm{~h}$.

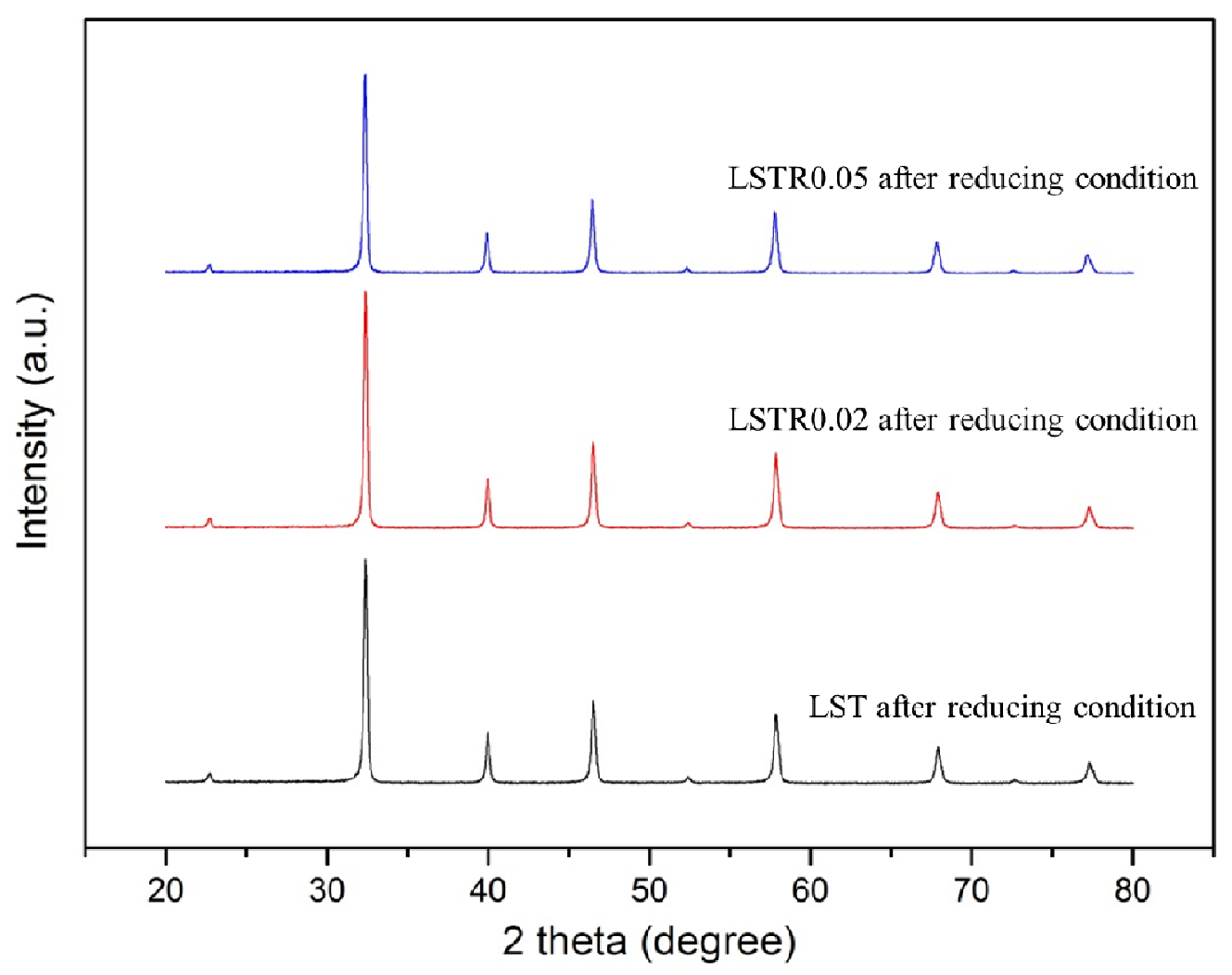

Figure 2. XRD patterns of synthesized powder $\mathrm{La}_{0.4} \mathrm{Sr}_{0.6} \mathrm{TiO}_{3}, \mathrm{La}_{0.4} \mathrm{Sr}_{0.6} \mathrm{Ti}_{0.98} \mathrm{Ru}_{0.02} \mathrm{O}_{3}$ and $\mathrm{La}_{0.4} \mathrm{Sr}_{0.6} \mathrm{Ti}_{0.95} \mathrm{Ru}_{0.05} \mathrm{O}_{3}$ after exposing at $900{ }^{\circ} \mathrm{C}$ in wet $\mathrm{H}_{2}$ for $10 \mathrm{~h}$.

In case of cathode part, LSM $\left(\mathrm{La}_{0.85} \mathrm{Sr}_{0.15} \mathrm{MnO}_{3}\right)$, which is generally used as cathode, can react with YSZ chemically leading to formation of $\mathrm{La}_{2} \mathrm{Zr}_{2} \mathrm{O}_{7}$. The $\mathrm{La}_{2} \mathrm{Zr}_{2} \mathrm{O}_{7}$ phase formation at the cathode/electrolyte leads to negative effects to the performance (10). The compatibility with YSZ electrolyte is also an important factor in not only cathode but also in anode due to it is also attached with electrolyte directly. As shown in Figure 3, all of XRD patterns of LST/YSZ and LSTR/YSZ mixtures after heat treatment at $1300{ }^{\circ} \mathrm{C}$ for $10 \mathrm{~h}$ in air show distinguishable peaks of the perovskite and YSZ, and there were no new peaks implying that no reaction was carried on between YSZ and the perovskite. 


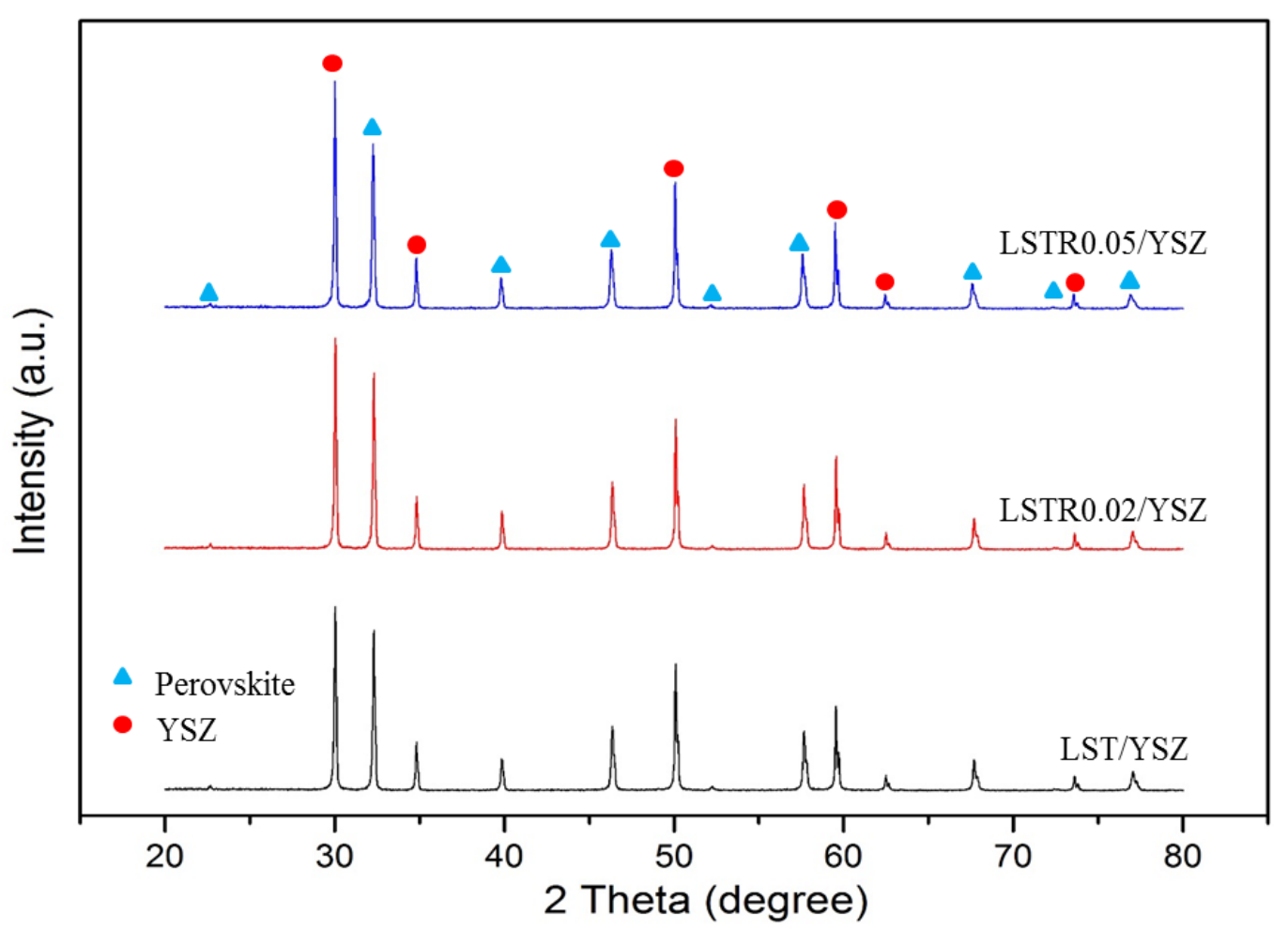

Figure 3. XRD patterns of YSZ mixed with $\mathrm{La}_{0.4} \mathrm{Sr}_{0.6} \mathrm{TiO}_{3}, \mathrm{La}_{0.4} \mathrm{Sr}_{0.6} \mathrm{Ti}_{0.98} \mathrm{Ru}_{0.02} \mathrm{O}_{3}$ and $\mathrm{La}_{0.4} \mathrm{Sr}_{0.6} \mathrm{Ti}_{0.95} \mathrm{Ru}_{0.05} \mathrm{O}_{3}$ powders after heat treatment at $1300^{\circ} \mathrm{C}$ for $10 \mathrm{~h}$ in air.

The total electrical conductivity in wet $\mathrm{H}_{2}$ with the prepared bars sintered in $10 \%$ $\mathrm{H}_{2} / \mathrm{Ar}$ as function of temperature and doping amount of Ru is shown in Figure 4. All of the measured values were corrected in order to eliminate the error that comes from the difference in relative densities of each sample [1]. $\sigma_{\text {corr }}$ is corrected electrical conductivity, $\sigma_{\text {exp }}$ is measured electrical conductivity and $d_{\text {rel }}$ is relative density obtained by Archimedes principle.

$$
\sigma_{\text {corr }}=\sigma_{\exp } /\left(2 *\left(\left(\mathrm{~d}_{\text {rel }} / 100\right)-0.5\right)\right)
$$

All of the LST and LSTRs bars sintered in reducing atmosphere show much higher electrical conductivity compared with the minimum required value for the alternative anode materials $(\sim 1 \mathrm{~S} / \mathrm{cm})$ (1). Generally, pure LST shows metallic behavior that electrical conductivity increases as temperature decreases corresponding to the published literature (11). In low oxygen partial pressure condition, $\mathrm{Ti}^{4+}$ gradually reduced to $\mathrm{Ti}^{3+}$ by electron which occurs from oxygen reduction in lattice. And, when the concentration of $\mathrm{Ti}^{3+}$ is higher than the certain critical value, the spare electrons go into conduction band. Then the metallic behavior is expressed $(11,12)$ as shown in the Figure 4. It was expected that all prepared samples have high concentration of $\mathrm{Ti}^{3+}$ due to severe reduction sintering atmosphere. And the electrical conductivity behavior of LSTRs also follows the trend of LST. Although the electrical conductivity trend decreases as temperature increases due to metallic behavior, still high electrical conductivity was achieved using LST, LSTR0.02 and LSTR0.05 with $350.6 \mathrm{~S} / \mathrm{cm}, 342.4 \mathrm{~S} / \mathrm{cm}$ and 179.1 $\mathrm{S} / \mathrm{cm}$ at $900{ }^{\circ} \mathrm{C}$, respectively. 

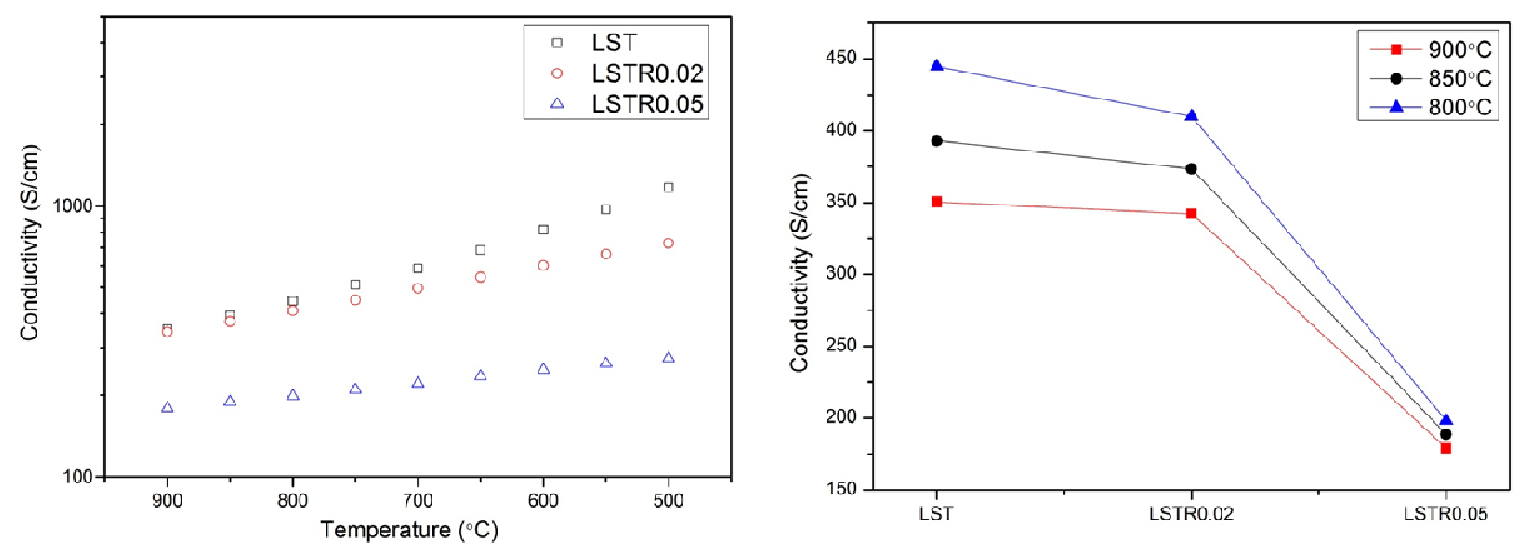

Figure 4. Electrical conductivity of bar sintered at $1400{ }^{\circ} \mathrm{C}$ in $10 \% \mathrm{H}_{2} / \mathrm{Ar}$ for $5 \mathrm{~h}$ as a function of temperature and doping amount of $\mathrm{Ru}$ in wet $\mathrm{H}_{2}$.

The electrical conductivity decreases with increasing doping amount of $\mathrm{Ru}$ in a range of the overall measuring temperature. After electrical measurement, sintered bar were examined by XRD to confirm these worsening effect of $\mathrm{Ru}$ as shown in Figure 5. Although all samples show the chemical stability after exposing at $900{ }^{\circ} \mathrm{C}$ in wet $\mathrm{H}_{2}$ for $10 \mathrm{~h}$ which is similar to the typical operating condition of anode as mentioned above, the ruthenium metal species could be precipitated when exposed to harsher conditions such as sintering condition, $1400{ }^{\circ} \mathrm{C}$ in $10 \% \mathrm{H}_{2} / \mathrm{Ar}$ for $5 \mathrm{~h}$. Furthermore, the peaks of $\mathrm{Ru}$ metal species appeared more clearly with increasing doping amount of $\mathrm{Ru}$ in XRD patterns of bars after electrical conductivity measurement. Therefore, it seems to be related to the low electrical conductivity.

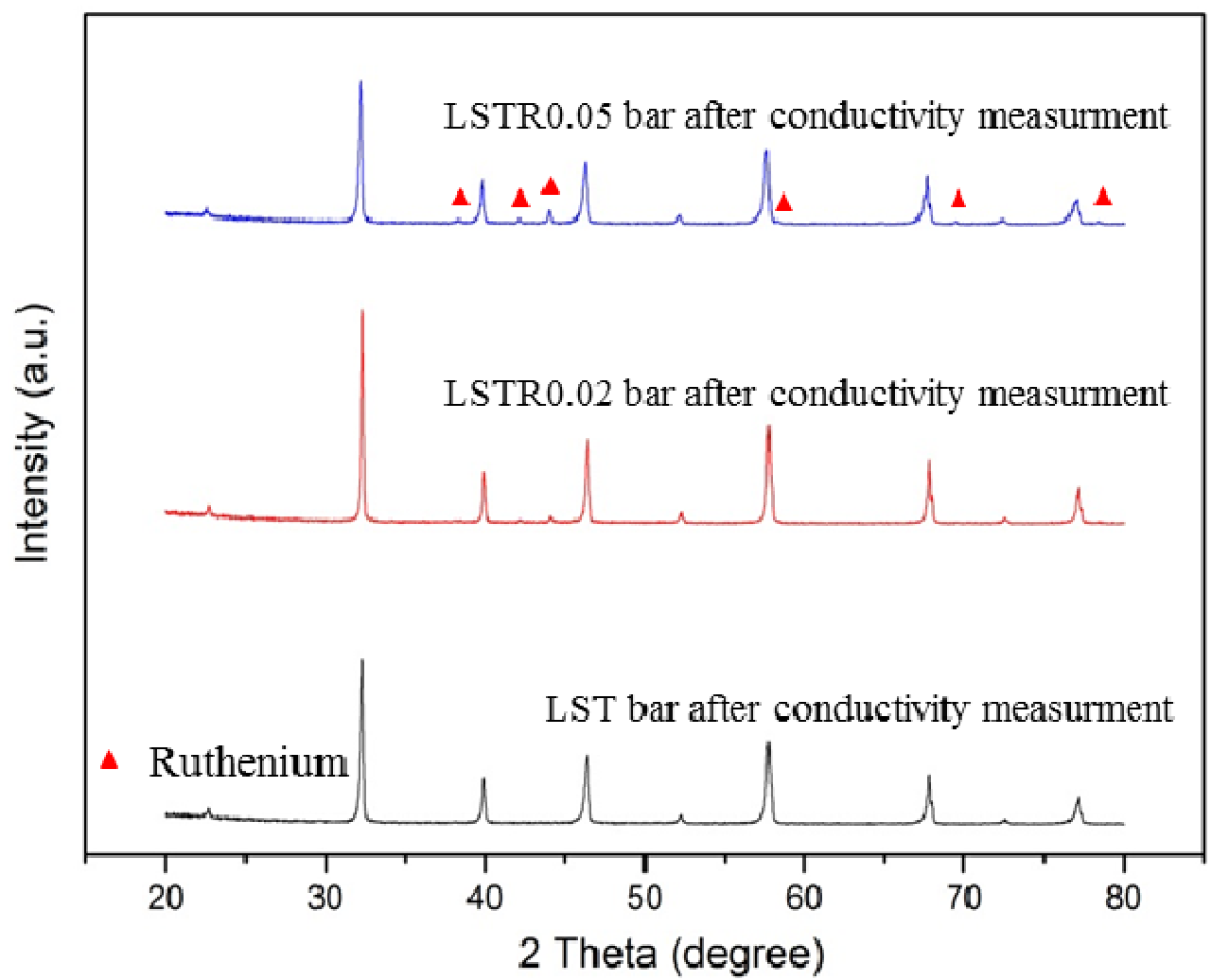

Figure 5. XRD patterns of $\mathrm{La}_{0.4} \mathrm{Sr}_{0.6} \mathrm{TiO}_{3}, \quad \mathrm{La}_{0.4} \mathrm{Sr}_{0.6} \mathrm{Ti}_{0.98} \mathrm{Ru}_{0.02} \mathrm{O}_{3}$ and $\mathrm{La}_{0.4} \mathrm{Sr}_{0.6} \mathrm{Ti}_{0.95} \mathrm{Ru}_{0.05} \mathrm{O}_{3}$ sintered bar after electrical conductivity measurement. 


\section{Conclusion}

In order to improve the catalytic properties of LST, Ru doped LST $\left(\mathrm{La}_{0.4} \mathrm{Sr}_{0.6} \mathrm{Ti}_{1-}\right.$ $\left.{ }_{x} \mathrm{Ru}_{\mathrm{x}} \mathrm{O}_{3}, \mathrm{x}=0,0.02,0.05\right)$ powders were synthesized by complex EDTA-citrate method showing well crystallinity and cubic type structure. And reducing stability and chemical compatibility with YSZ electrolyte were studied. It indicates that LST, LSTR0.02 and LSTR0.05 were stable at $900{ }^{\circ} \mathrm{C}$ in wet $\mathrm{H}_{2}$ for $10 \mathrm{~h}$ and no reactivity with YSZ was obtained after heat treatment at $1300^{\circ} \mathrm{C}$ for $10 \mathrm{~h}$ in air.

The electrical conductivities of LST, LSTR0.02 and LSTR0.05 sintered at $1400{ }^{\circ} \mathrm{C}$ in $10 \% \mathrm{H}_{2} / \mathrm{Ar}$ for $5 \mathrm{~h}$ exhibit $350.6 \mathrm{~S} / \mathrm{cm}, 342.4 \mathrm{~S} / \mathrm{cm}$ and $179.1 \mathrm{~S} / \mathrm{cm}$ at $900{ }^{\circ} \mathrm{C}$ in wet $\mathrm{H}_{2}$ condition, respectively. However, Ru metal species can be precipitated from lattice when exposed to sintering condition, $1400{ }^{\circ} \mathrm{C}$ in $10 \% \mathrm{H}_{2} / \mathrm{Ar}$ for $5 \mathrm{~h}$. So, the optimization of sintering condition as well as additional electrochemical and catalytic properties measurements should be carried out.

\section{Acknowledgments}

This work was supported by the National Research Foundation of Korea (NRF) grant funded by the Korea government (MEST) (No. 2012R1A2A2A03047613).

\section{References}

1. A. Atkinson, S. Barnett, R.J. Gorte, J.T.S. Irvine, A.J. Mcevoy, M. Mogensen, S.C. Singhal and J. Vohs, Nature Materials., 3, 17 (2004).

2. J.T.S. Irvine and A. Sauvet, Fuel Cells, 1(3-4), 205 (2001).

3. D. Sarantaridis, and A. Atkinson, Fuel Cells, 7(3), 246 (2007).

4. O. A. Marina, N. L. Canfield, and J. W. Stevenson, Solid State Ionics, 149, 21 (2002).

5. R. Mukundan, E.L. Brosha, and F.H. Garzon, Electrochem. Solid-State Lett., 7, A5 (2004).

6. Q. X. Fu, F. Tietzz and D. Stöver, J. Electrochem. Soc., 153, D74 (2006).

7. J. C. Ruiz-Morales, J. Canales-Vázquez, C. Savaniu, D. Marrero-López, W. Zhou and J. T. S. Irvine, Nature, 439, 568 (2006).

8. C. Périllat-Merceroz, G. Gauthier, P. Roussel, M. Huvé, P. Gélin, and R. Vannier, Chem. Mater., 23, 1539 (2011).

9. J. Park, J. Zou, H. Yoon, G. Kim, and J. S. Chung, Int. J. Hydrogen Energy, 36, 6184 (2011).

10. C. Brugnoni, U. Ducati, and M. Scagliotti, Solid State Ionics, 76, 177 (1995).

11. S.Q. Hui and A. Petric, J. Electrochem Soc., 149, J1 (2002).

12. N. F. Mott, Rev. Mod. Phys., 40, 673 (1968). 